\title{
STRESS-STRAIN STATE OF BEAM CORRUGATED WEB UNDER PATCH LOADING
}

\author{
I.Y. Semchuk, \\ master \\ T.O. Nilova, \\ Ph.D. \\ Kyiv National University of Construction and Architecture \\ Povitroflotsky ave., 31, Kyiv, Ukraine 03680
}

\begin{abstract}
It's presented results of numerical investigation via the finite elements method (FEM) of stressstrain state of beam corrugated web under local load action in its plane. It's concluded that the values of local normal stresses at the level of the web and the flange connection are directly dependent on the web thickness, the flexural and the longitudinal rigidity of the flanges and virtually don't depend on the web height. A practical technique for determining the limit values of local normal stresses in the web and its stress-strain state is developed.
\end{abstract}

Keywords: corrugated web, stress-strain state, strength condition, patch loading

\section{Introduction}

Steel I-beams with sinusoidally corrugated webs becomes more popular in modern building practice. They are mostly used in slab's constructions of light industrial and civil buildings frameworks. Usually it is girders with span less than $30 \mathrm{~m}$, and also, but rarely, it is columns.

Wide usage of elements with corrugated webs caused by its constructive simplicity and economy (small steel consumption, highly mechanized and robotic methods of its produce usage, transit simplicity, and ease of its preassembly into major units).

One of the insufficiently resolved problems, related to applying of such Ibeams, is a behavior of its corrugated webs under patch loadings.

According to Eurocode 3 [1] there are three following cases, when limit state can appear in unstiffened plane web under patch loading:

- plastic strains appearance in the region of the web connection with the flange;

- web local buckling in region of patch loading action;

- general web buckling form (one or more corrugations) over the entire height.

The simplest condition for not appearance of plastic strains in the web can be written by the following formula [3]:

$$
F=c_{0} t_{w} f_{y},
$$

where $c_{0}$ - the design length of the local load application to the beam web, which is calculated by the next formula:

$$
c_{0}=c+k\left(t_{f}+a\right),
$$

$c$ - the length of the local load application to the bean flange; $k$-coefficient, which depends on deformability of element, which passes the load to the beam $(k=2 \ldots .5) ; t_{f}$-flange thickness; $t_{w}$-web thickness; $a$-thickness of welded seam, which joins web with flange; $f_{y}-$ yield strength of web steel. 
As the experimental researches are shown, this method gives reliable but inflated results (in some cases more than $200 \%$ ).

If loaded element is rigid, effective patch loading distribution width should be calculated by the formula [7]:

$$
l_{e f}=\eta \sqrt[3]{\frac{I_{f}}{t_{f}}},
$$

where $\eta$-coefficient, which for beams with plane web depends on rigidity connection of web with flange (for welded beams $\eta=3.26$ ); $I_{y}$ - moment of inertia of flange section.

The formula was obtained for low beams, which under local loads has local buckling at the level of web and flange connection (Broude terminology [7]). Also this formula doesn't account the length $c$ of the local load application.

On 1999 Pasternak and Brańka [5] investigated the beam's geometrical parameters influence on load-carrying capacity under patch loading. It was set that web and flange thicknesses significantly influence on load-carrying capacity. But location of load relatively to web points (comb, zero point) doesn't have such influence.

Pasternak and Brańka proposed the formula for calculation load-carrying capacity of corrugated web under local load:

$$
F=10\left(\frac{W}{I_{y w} / t_{w}}\right)^{0.4} \cdot 2 \cdot f \cdot t_{w} \cdot f_{y},
$$

where $W$-section modulus of loaded flange; $I_{y w}$-moment of inertia of corrugation (wave) relatively to beam axis; $f$-wave amplitude with the projection length $m$ (Fig. 1).

Equation (4) doesn't account the width of load application, which causes underestimating the load-carrying capacity in case of large length (Kuchta [6]).

In numerical investigations Luo and Edlund ([8] and [9]) proved that loadcarrying capacity of corrugated web significantly depends on local load distribution width $l_{b}$ and beam web thickness $t_{w}$.

It should be noted that all discussed above formulae aren't sufficient scientific justified, don't account flange flexural rigidity and shear stresses between flange and web. So results with accounting of these formulae mismatch with experimental results and need correction.

The article [10] shows, that maximum matching to experimental results is achieved after usage of numerical FEM.

This paper proposes numerically analytic method for corrugated web limit state determination under patch loading, which is based on stress-strain state analysis of physico-mathematical models via FEM.

For the limit value of the local force $F$ its value is taken, in which a local stress equal to the yield strength of the web steel $f_{y}$ occurs in the beam web under the local load.

\section{Research problem formulation}

In this paper we consider an improved procedure for determining the web load-carrying capacity under the action of local load. 
In real constructions the load passes to the beam through hot rolled or cold bended angles, which supporting length along beam length is usually $l_{b}=60 \ldots 80 \mathrm{~mm}$ (Fig. 1, $a$ ). Also transversal elements can be used instead of angles. It made from sheet with width $10 \ldots 15 \mathrm{~mm}$ (Fig. 1, $b$ ). The length of transversal elements is always equal to beam flange width.

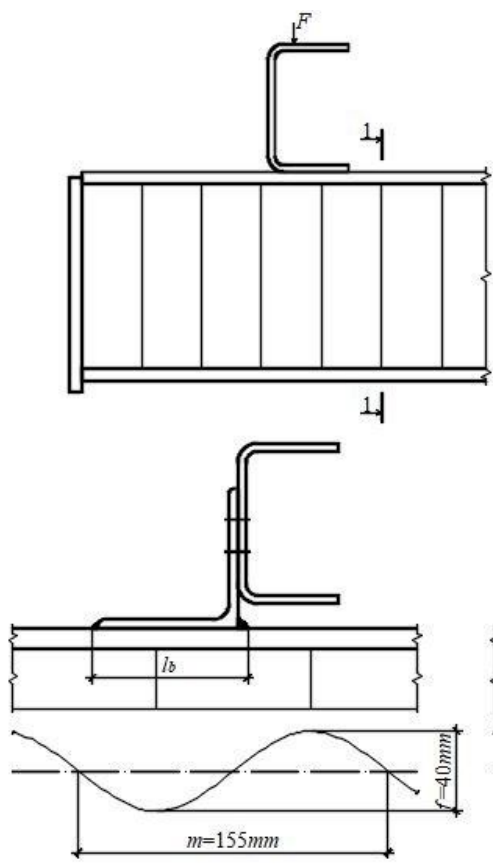

(a)

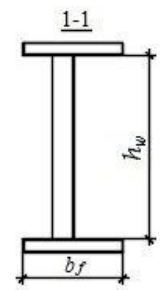

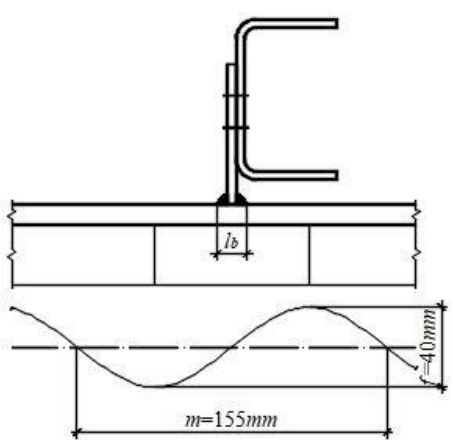

(b)

Fig. 1. The supporting nodes of purlins on the beam with corrugated web

Stress-strain state of transversally corrugated webs was analyzed in the program LIRA 10.6. All calculations were done on physico-mathematical models, which had been created according to standard corrugated profiles range of company Zeman. Used profile models WTA, WTB and WTC had such geometrical parameters:

- web thickness $t_{w}=2,0 ; 2,5 ; 3,0 \mathrm{~mm}$ respectively;

- web height $h_{w}=500 \mathrm{~mm}$;

- flange width $b_{f}=200 \mathrm{~mm}$;

- flange thickness $t_{f}=8 ; 12 ; 16 ; 20 ; 25 ; 30 ; 40 \mathrm{~mm}$;

- model length $L=1860 \mathrm{~mm}$.

Beam models were loaded by two options of load with the same resultant force $(F=38.05 \mathrm{kN})$ and different lengths of its action area $\left(l_{b}=15 \mathrm{~mm}\right.$ and $77.5 \mathrm{~mm}$ ) and width $40 \mathrm{~mm}$ (such width was set because of corrugation amplitude dimension $f$, which is $40 \mathrm{~mm}$ ) (Fig. 2). The load was applied on beam axis in such way, that composite force was acting through change in corrugation curvature. 


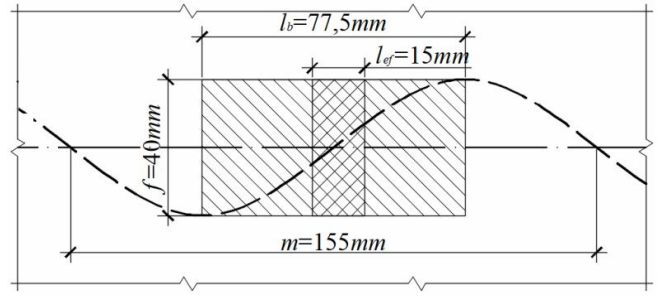

Fig. 2. Load action regions

Beams were modeled by finite elements of thin shell. Considering that beams with corrugated webs is the third class construction by its stress-strain state $[1,2]$, all strength analyses were done under the condition of elastic behavior of steel. The mark of the steel was E335

$\left(f_{y}=305 \mathrm{MPa}\right)$.

\section{Numerical results}

After carrying out the necessary calculations via LIRA it was established that the height of the beam web practically did not affect the magnitude of the maximum normal stresses at the level of its connection with the flange. Web and flange thickness, and supporting length of purlin on the beam $\left(l_{b}\right)$ have significant influence on the stress-strain state of beam web.

As the normal and tangential stresses distribution diagrams show (Fig. 4), maximum values are concentrated within one corrugation, and not lower than $10 \ldots 20$ web thicknesses from connection of web and flange (Fig. 3). It should be noted, that both diagrams (Fig. 3 and Fig. 4) based on results from calculations of beams with flange thickness $8 \mathrm{~mm}$. At that the diagram on Fig. 3 displays the local load distributed on the lengths $l_{b}=15 \mathrm{~mm}$.

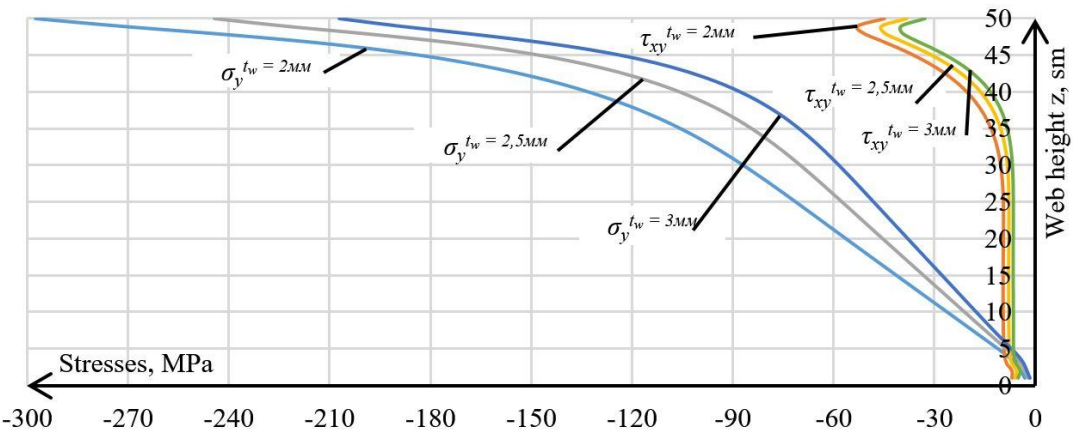

Fig. 3. The diagram of normal and tangential stresses distribution along beam web's height

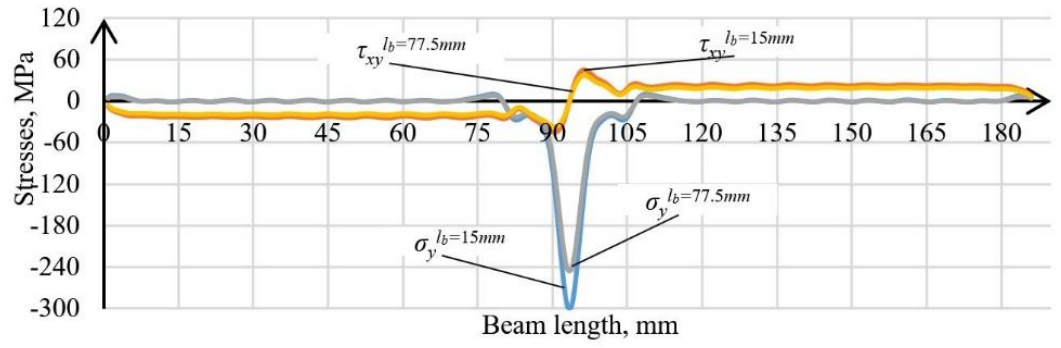

Fig. 4. The diagram of normal and tangential stresses distribution along beam length 
Nowadays, design codes $[1,2]$ suggest to calculate local stresses under force by the next formula:

$$
\sigma_{y, l o c}=\frac{F}{t_{w} l_{e f}} \leq f_{y},
$$

where $l_{e f}-$ design stresses distribution length taking into account web corrugating:

$$
l_{e f}=\left(l_{b}+2 t_{f}\right) 2 s / m
$$

$l_{b}$ - the length of the local load application along the beam; $s$ - the length of the half-wave sine curve.

The $2 s / m$ ratio takes into account the increase of the corrugated web length in comparison with the flat web.

It should be noted, that the formula (5) isn't sufficient scientific justified, and doesn't account the flange flexural rigidity and shear stresses between the flange and the web. So results which were got by this formula, need correction.

More accurate values $\sigma_{y . l o c}$ were got with usage of FEM via LIRA. It was done values comparison of stresses (Table 1), which were got via FEM $\left(\sigma_{\text {y.loc }}{ }^{F E M}\right)$, with those, which were calculated by formula $(5)\left(\sigma_{y . l o c}{ }^{(5)}\right)$. So it was set, that these stresses were changed by different rules (Table 1). If the purlin supporting length is insignificant $\left(l_{b}=15 \mathrm{~mm}\right), \sigma_{y . l o c}{ }^{F E M}$ always are much smaller than $\sigma_{y . l o c}{ }^{(5)}$. If to increase contribution length $\left(l_{b}=77.5 \mathrm{~mm}\right)$ and flange thickness is small $\left(t_{f}=8 \ldots 12 \mathrm{~mm}\right), \sigma_{\text {y.loc }}^{F E M}$ are higher than $\sigma_{\text {y.loc }}{ }^{(5)}$. But with flange thickness increasing $\sigma_{\text {y.loc }} F E M$ is becoming smaller than $\sigma_{\text {y.loc }}$ (5).

To simplify the calculations, approximate values of normal stresses $\sigma_{y \cdot l o c}$ can be found with the diagram (Fig. 5) depending on the web thickness $t_{w}$ and the flange thickness $t_{f}$ when the purlin supporting lengths $l_{b}=15 \mathrm{~mm}$ and $l_{b}$ $=77,5 \mathrm{~mm}$.

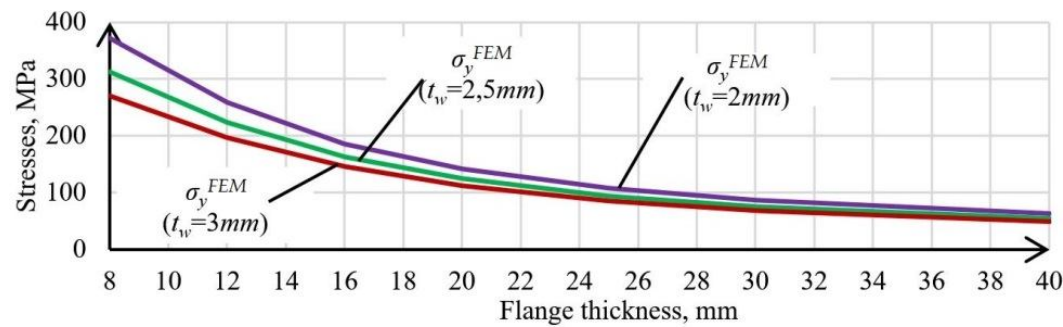

(a)

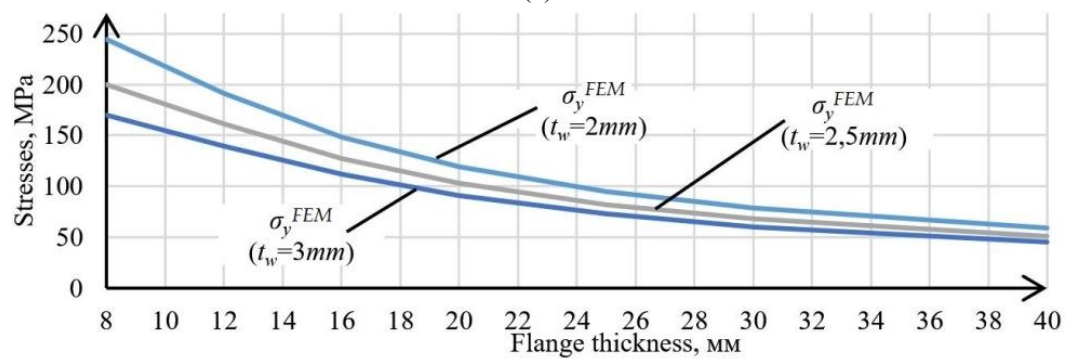

(b)

Fig. 5. Dependence of $\sigma_{y . l o c}$ on $t_{w}$ and $t_{f}$ when $l_{b}=15 \mathrm{~mm}$ (a) and $l_{b}=77,5 \mathrm{~mm}$ (b) 
Table 1

Local stress $\left(\sigma_{y . l o c}{ }^{F E M}\right.$ and $\left.\sigma_{y . l o c}{ }^{(5)}\right)$ values comparison

\begin{tabular}{|c|c|c|c|c|c|c|c|c|c|c|c|c|c|c|c|c|}
\hline \multirow{3}{*}{ 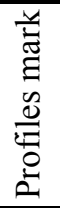 } & \multirow{3}{*}{$\begin{array}{l}\Xi \\
\Xi \\
\underline{\Xi}\end{array}$} & \multirow{3}{*}{$\begin{array}{l}\Xi \\
\Xi \\
\approx\end{array}$} & \multicolumn{14}{|c|}{$t_{f}, \mathrm{~mm}$} \\
\hline & & & \multicolumn{2}{|c|}{8} & \multicolumn{2}{|c|}{12} & \multicolumn{2}{|c|}{16} & \multicolumn{2}{|c|}{20} & \multicolumn{2}{|c|}{25} & \multicolumn{2}{|c|}{30} & \multicolumn{2}{|c|}{40} \\
\hline & & & $\sum_{\mid \underline{I}}$ & $\sqrt{2}$ & $\sum_{\substack{\mid \pm I \\
I}}$ & $\sqrt[n]{6}$ & 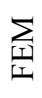 & $\sqrt{6}$ & 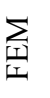 & $\sqrt{6}$ & $\sum_{\substack{1 \\
I}}$ & $\sqrt{2}$ & 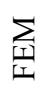 & $\sqrt{2}$ & $\sum_{\substack{1 \\
I}}$ & $\sqrt{2}$ \\
\hline \multirow[t]{2}{*}{$\varangle$} & \multirow{2}{*}{$\sim$} & 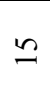 & $\begin{array}{l}\text { in } \\
\text { s. } \\
\text { n }\end{array}$ & $\begin{array}{l}\infty \\
\sigma_{0} \\
\infty \\
n \\
n\end{array}$ & $\begin{array}{l}\infty \\
\infty \\
\infty \\
\sim\end{array}$ & 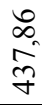 & $\begin{array}{l}\hat{\text { }} \\
\stackrel{\infty}{\infty}\end{array}$ & î & $\underset{\nexists}{\stackrel{\Re}{\Xi}}$ & $\begin{array}{l}\overrightarrow{0} \\
\text { î. } \\
\text { m. }\end{array}$ & $\begin{array}{l}\stackrel{8}{2} \\
\text { - }\end{array}$ & $\begin{array}{l}\hat{\Omega} \\
\stackrel{\sim}{\hat{n}}\end{array}$ & \begin{tabular}{l}
\multirow{2}{0}{} \\
$\infty$
\end{tabular} & 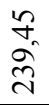 & $\begin{array}{l}\text { న } \\
\text { రి }\end{array}$ & $\begin{array}{l}\stackrel{2}{\vec{G}} \\
\stackrel{-}{=}\end{array}$ \\
\hline & & $\stackrel{n}{\wedge}$ & $\begin{array}{l}\text { बे } \\
\underset{\sim}{\sim}\end{array}$ & $\begin{array}{l}\stackrel{\alpha}{.} \\
\stackrel{\infty}{0}\end{array}$ & 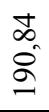 & $\begin{array}{l}\stackrel{g}{a} \\
0_{0}^{0}\end{array}$ & $\begin{array}{l}\infty \\
+ \\
\infty \\
+ \\
+ \\
+\end{array}$ & $\begin{array}{l}\infty \\
0 \\
\text { in } \\
\text { n. }\end{array}$ & $\begin{array}{l}\stackrel{\partial}{\partial} \\
\triangleq\end{array}$ & \begin{tabular}{l}
$n$ \\
ñ \\
\multirow{2}{*}{}
\end{tabular} & $\begin{array}{l}\stackrel{2}{\circ} \\
\dot{\sigma}\end{array}$ & $\begin{array}{l}\stackrel{2}{\hat{6}} \\
\stackrel{0}{2}\end{array}$ & $\begin{array}{l}\infty \\
\infty \\
\infty\end{array}$ & $\begin{array}{l}\infty \\
\sim \\
\hat{N} \\
\end{array}$ & $\begin{array}{l}n \\
0 \\
0\end{array}$ & $\begin{array}{l}\stackrel{9}{+} \\
\stackrel{ }{\Xi}\end{array}$ \\
\hline \multirow{2}{*}{$\stackrel{n}{3}$} & \multirow{2}{*}{$\stackrel{\sim}{\sim}$} & $\cong$ & $\frac{\dot{m}}{m}$ & $\begin{array}{l}\tilde{2} \\
\stackrel{\Im}{7}\end{array}$ & $\begin{array}{l}\tilde{a} \\
\tilde{a}\end{array}$ & $\begin{array}{l}\text { ते } \\
\text { है }\end{array}$ & $\begin{array}{l}\text { ¿ } \\
\text { త్ర }\end{array}$ & 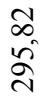 & $\begin{array}{l}\text { In } \\
\stackrel{+}{I}\end{array}$ & $\begin{array}{l}\bar{\sigma} \\
\text { bे } \\
\text { సै }\end{array}$ & $\begin{array}{l}\text { Tे } \\
\dot{\sigma}\end{array}$ & $\begin{array}{l} \pm \\
\frac{\vec{a}}{\sim}\end{array}$ & 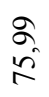 & $\begin{array}{l}\stackrel{n}{a} \\
\sigma\end{array}$ & $\begin{array}{l}\hat{n} \\
\dot{n}\end{array}$ & $\begin{array}{l}\hat{\sigma} \\
\hat{\Omega} \\
\Omega\end{array}$ \\
\hline & & $\stackrel{n}{N}$ & ?. & $\begin{array}{l}\stackrel{2}{1} \\
\dot{J}\end{array}$ & $\begin{array}{l}\circ \\
\stackrel{0}{6}\end{array}$ & $\begin{array}{l}n \\
n \\
\dot{f} \\
=\end{array}$ & 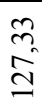 & $\begin{array}{l}\stackrel{8}{ } \\
\stackrel{\jmath}{\cong}\end{array}$ & $\begin{array}{l}\text { m } \\
0 \\
\text { ô } \\
0\end{array}$ & $\begin{array}{l}\infty \\
\infty \\
\stackrel{\infty}{\Xi} \\
=\end{array}$ & $\begin{array}{l}n \\
\tilde{o} \\
\infty \\
\infty\end{array}$ & $\begin{array}{l}\text { ㅇ. } \\
\text { ô }\end{array}$ & $\begin{array}{l}8 \\
\infty \\
\infty \\
0\end{array}$ & $\begin{array}{l}\hat{s} \\
\text { â } \\
0\end{array}$ & $\begin{array}{l}\infty \\
\stackrel{0}{n} \\
n^{2}\end{array}$ & $\begin{array}{l}2 \\
\stackrel{\infty}{ }\end{array}$ \\
\hline \multirow{2}{*}{$\begin{array}{c}0 \\
3\end{array}$} & \multirow{2}{*}{$m$} & 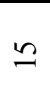 & $\begin{array}{l}\stackrel{?}{\stackrel{2}{\rho}} \\
\stackrel{2}{N}\end{array}$ & $\begin{array}{l}\stackrel{2}{n} \\
\text { in }\end{array}$ & $\begin{array}{l}\tilde{a} \\
\hat{a}\end{array}$ & $\begin{array}{l}\bar{\sigma} \\
\vec{\AA}\end{array}$ & 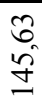 & $\begin{array}{l}\bar{n} \\
\text { ô } \\
\text { dn }\end{array}$ & $\begin{array}{l}\cong \\
\Xi\end{array}$ & 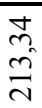 & $\begin{array}{l}\partial \\
\dot{\infty}\end{array}$ & $\begin{array}{l}\text { ָु } \\
\text { i } \\
\infty\end{array}$ & $\frac{I}{\infty}$ & $\begin{array}{l}\hat{\sigma} \\
\hat{n} \\
\hat{n}\end{array}$ & $\begin{array}{l}\mathbb{N} \\
\infty \\
\infty\end{array}$ & $\begin{array}{l}\tilde{n} \\
\stackrel{\Omega}{\cong}\end{array}$ \\
\hline & & $\stackrel{n}{\approx}$ & $\begin{array}{l}\infty \\
0 \\
0\end{array}$ & 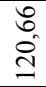 & $\begin{array}{l}\text { त् } \\
\text { ले }\end{array}$ & $\begin{array}{l}\stackrel{\Omega}{\Xi} \\
\underline{\Xi}\end{array}$ & $\begin{array}{l}\tilde{\Xi} \\
\Xi\end{array}$ & $\begin{array}{l}\mathbb{N} \\
\stackrel{d}{O}\end{array}$ & $\begin{array}{l}\infty \\
\hat{\Omega} \\
\hat{\Omega}\end{array}$ & $\begin{array}{l}\tilde{N} \\
\infty \\
\infty\end{array}$ & $\stackrel{i}{i}$ & $\begin{array}{l}\text { I } \\
\vec{a}\end{array}$ & $\begin{array}{l}\text { के } \\
\hat{8}\end{array}$ & $\begin{array}{l}n \\
\approx \\
\infty\end{array}$ & $\begin{array}{l}\infty \\
0 \\
i\end{array}$ & $\begin{array}{l}8 \\
i \\
i\end{array}$ \\
\hline
\end{tabular}

In this paper while using the formula (5) it is proposed to calculate the design length $l_{e f}$ taking into account flange flexural rigidity $I_{f}$ and web thickness $t_{w}$ by the formula (3) with introduction of new refined coefficient $\psi$ instead of the coefficient $\eta$. The procedure for determining the value of this coefficient besides flexural rigidity of the flange takes into account the deformability level of its connection with the corrugated web. For corrugated beams the coefficient $\psi$ should be taken from Table 2 which is the basis for its determination for any geometric parameters of the beams according to the company Zeman range.

Table 2

Coefficient $\psi$ values for beams with flange width $b_{f}=200 \mathrm{~mm}$

\begin{tabular}{|c|c|c|c|c|c|c|c|c|c|}
\hline \multirow{2}{*}{ 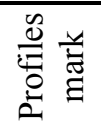 } & \multirow{2}{*}{ 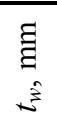 } & \multirow{2}{*}{ 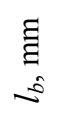 } & \multicolumn{7}{|c|}{$t_{f}, \mathrm{~mm}$} \\
\hline & & & 8 & 12 & 16 & 20 & 25 & 30 & 40 \\
\hline \multirow{2}{*}{$\grave{3}<$} & \multirow{2}{*}{2} & 15,5 & 31,48 & 30,21 & 31,48 & 33,10 & 34,78 & 35,98 & 37,34 \\
\hline & & 77,5 & 48,07 & 40,97 & 39,50 & 39,36 & 39,52 & 39,66 & 39,72 \\
\hline \multirow{2}{*}{$\xi \infty$} & \multirow{2}{*}{2,5} & 15,5 & 32,29 & 30,18 & 31,02 & 32,48 & 34,19 & 35,47 & 37,02 \\
\hline & & 77,5 & 50,47 & 41,82 & 39,69 & 39,32 & 39,42 & 39,58 & 39,72 \\
\hline \multirow{2}{*}{$\$ 0$} & \multirow{2}{*}{3} & 15,5 & 33,07 & 30,28 & 30,73 & 32,03 & 33,70 & 35,04 & 36,74 \\
\hline & & 77,5 & 52,71 & 42,73 & 39,98 & 39,35 & 39,36 & 39,52 & 39,71 \\
\hline \multicolumn{3}{|c|}{$I_{f}$} & 0,85 & 2,88 & 6,83 & 13,33 & 26,04 & 45 & 106,67 \\
\hline
\end{tabular}


The given coefficients $\psi$ are calculated by the formula:

$$
\psi=\frac{F}{\sigma_{y, l o c} t_{w} \sqrt[3]{t_{f} / t_{w}}}=\frac{F}{\sigma_{y, l o c} \sqrt[3]{t_{w}^{2} I_{f}}} .
$$

Also obtained values $\psi$ account the load action length along the beam flange $l_{b}=15 \mathrm{~mm}$ or $l_{b}=77.5 \mathrm{~mm}$ (Table 2$)$. When web thickness $\left(t_{w}\right)$ is given, $\psi$ values depend only on flange moment of inertia $\left(I_{f}=b_{f} t_{f}{ }^{3} / 12\right)$. When flange width or thickness is different to table values, the $\psi$ values should be calculated with using of the last row in Table 2 and linear interpolation.

If the flange thickness $t_{f}$ differs from the values given in Table 2 or the value $15 \mathrm{~mm} \leq l_{b} \leq 77,5 \mathrm{~mm}$ then linear interpolation method should be used to determine the coefficient $\psi$.

It should be noted, that the web has composite stress-strain state at the level of connection with the flange. Such condition caused by deformation continuity effect. The appeared stresses $\left(\sigma_{x . l o c}\right.$ and $\left.\tau_{x y . l o c}\right)$ could be calculated as a component of $\sigma_{y . l o c}$. At that for practical calculations it can be taken the average values $\sigma_{x}=(0.21 \div 0.25) \sigma_{y}$ and $\tau_{x y}=(0.2 \div 0.3) \sigma_{y}$.

As the Huber-Mises-Hencky theory says, the condition of steel elastic behavior is verified by formula:

$$
\sigma_{e q v}=\sqrt{\sigma_{y}^{2}+\left(\sigma_{x}+\sigma_{x, l o c}\right)^{2}-\sigma_{y}\left(\sigma_{x}+\sigma_{x, l o c}\right)+3\left(\tau_{g}+\tau_{x y, l o c}\right)^{2}} \leq \beta f_{y} .
$$

Tangential stresses $\tau_{x y}$ should be calculated as sum $\tau_{x y}=\tau_{Q}+\tau_{x y . l o c}$, where $\tau_{Q}$ is calculated from transverse force in the section. Taking in accounting that plastic strains are generated in the web on the small length under local force, then it is suggested in case of compressed flange take coefficient $\beta=1.15$, and in case of tensed flange take $\beta=1.30$. In addition, normal stresses should not be higher than yield strength of steel $f_{y}$.

For practical calculations the value of the limiting force $F$ under the condition of strength is recommended to be determined by the formula:

$$
F=t_{w} l_{e f} f_{y},
$$

where $l_{e f}$ should be taken using the coefficient $\psi$ (Table 2).

\section{Conclusions}

It is proved that stress-strain state of beam corrugated web under the action of the local patch loading should be determined taking into account the distribution length of the local load, the web thickness, the flange rigidity and the behavior of its connection with the web using the FEM.

A scientifically grounded technique for determining stress-strain state of beam corrugated web is developed with sufficient accuracy. This procedure presented in tabular form and allows determining the limit value of local patch loading provided prevention of plastic strains.

\section{REFERENCES}

1. Eurocode No. 3 Design of Steel Structures. Part 1.1. General rules and rules for buildings (European Prestandard ENV-1993-1-1).

2. Eurocode No. 3, Design of Steel Structures. Part 1.5. Plated structural elements (EN 1993-1-5, 2008).

3. Siokola $W$., Wellstegträger. Herstellung und Anwendung von Trägern mit profiliertem Steg. Stahlbau 9/1997. - P. $596-605$. 
4. Ramberger G., Gutachten über die Berechnung von Geschweissten I-Trägern Mit Stegen Aus Gewellten Blechen. - O. Univ., Wien 1989 - not published.

5. Pasternak H., Brańka P., Tragverhalten von Wellstegträgern unter lokaler Lasteinleitung. Bauingenieur 5/1999. - P. $219-224$.

6. Kuchta K.R., Nośność i Sztywność Blachownic o Falistych środnikach. — Politechnika Krakowska. - Kraków 2004.

7. Broude B.M., Raspredelenie sosredotochennogo davleniya v metallicheskih balkah. (Distribution of concentrated pressure in metal beams) - Stroyizdat, Moskva - Leningrad 1950.

8. Luo R., Edlund B., Strength of Plate Girders with Trapezoidally Corrugated Webs in Shear or under Patch Loading - Proceedings of Nordic Steel Construction Conference, Malmö, $1995,-$ P. $79-86$.

9. Luo R. and Edlund B., Shear Capacity of Plate Girders with Trapezoidally Corrugated Webs. Thin-Webed Structures, - 1996, Vol. 26, No. 1, - P. $19-44$.

10. Kuchta K.R., Design of corrugated webs under patch load. - Advanced Steel Construction, 2007, — Vol. 3, - No. 4. - P. 737 - 751. https://doi.org/10.18057/IJASC.2007.3.4.3

Стаття надійшла до редакиї 12.10.2018 р.

Семчук І.Ю., Нілова Т.О.

\section{НАПРУЖЕНО-ДЕФОРМОВАНИЙ СТАН ГОФРОВАНОЇ СТІНКИ БАЛКИ ПРИ ЛОКАЛЬНОМУ НАВАНТАЖЕННІ}

Згідно сучасним нормам проектування, гофровані стінки зварних балок під дією локальних навантажень, прикладених до поясів в площині стінки, повинні перевірятися на міцність за умовою пружної роботи сталі. Але в наш час в нормах проектування науково обгрунтована методика такого розрахунку відсутня.

У роботі запропоновано чисельно-аналітичний метод визначення граничного стану гофрованої стінки при локальному навантаженні, який базується на аналізі за методом МСЕ напружено-деформованого стану фізико-математичних моделей, створених відповідно до сортаменту гофрованих профілів компанії Zeman. При аналізі міцності балки моделювалися СЕ тонкої оболонки за умовами пружної роботи сталі. Встановлено, що висота стінки практично не впливає на значення нормальних напружень в рівні ії з'єднання 3 поясами. Суттєвий вплив на величину локальних напружень надають товщина стінки і довжина розподілу локального навантаження.

Розроблено основоположну таблицю, яка дозволяє знайти всі необхідні дані для визначення максимального значення локальної навантаження за умовою пружної роботи сталі. У випадках, коли товщина поясу або довжина розподілу локального навантаження відрізняється від табличних значень, необхідно використовувати лінійну інтерполяцію.

Враховуючи, що в області спряження стінки 3 поясами діють одночасно локальні тангенціальні і нормальні напруження, міцність стінки слідує перевіряти за критерієм ХубераМізеса-Хенкі.

Ключові слова: гофрована стінка, напружено-деформований стан, умова міцності, локальне навантаження.

\section{Semchuk I.Y. , Nilova T.O.}

\section{STRESS-STRAIN STATE OF BEAM CORRUGATED WEB UNDER PATCH LOADING}

One of the insufficiently resolved problems related to the use of steel I-beams with sinusoidally corrugated webs that are becoming more popular in modern building practice is a behavior of its webs under patch loadings.

According to modern design codes corrugated webs of welded beams under patch loading action via on of the flanges in the web plane should be checked for strength under the condition of elastic behavior of steel. But nowadays standard scientific justified technique for such analyses is absent.

This paper proposes numerically analytic method for corrugated web limit state determination under patch loading, which is based on stress-strain state analysis via FEM of physico-mathematical models created according to standard corrugated profiles range of company Zeman.

In the strength analysis the beams were modeled by finite elements of thin shell under the condition of elastic behavior of steel. It's established that the web height practically don't have an effect on the values of normal stresses at the level of its connection with the flange. The web thickness and the distribution length of the patch loading exert the main impact on the value of local stresses.

A generic table that allows finding all necessary data to determine the maximum value of local patch loading under the condition of steel elastic behavior was developed. In the cases when flange thickness or distribution length of the patch loading is different to the table values it is necessary to use the linear interpolation method.

Considering that in the area of local stresses the tangential stresses act simultaneously with the normal stresses, the web strength is proposed to be checked by the Huber-Mises-Hencky criterion. 
The application of the developed technique makes it possible to determine with a given accuracy the value of local stresses in the web and, if necessary, to correct its thickness or the flange thickness. This procedure allows refining the required web thickness when patch local loading affects it and, thus, reduces consumption of steel.

Keywords: corrugated web, stress-strain state, strength condition, patch loading

\section{Семчук И.Ю., Нилова Т.А.}

\section{НАПРЯЖЕННО-ДЕФОРМИРОВАННОЕ СОСТОЯНИЕ ГОФРИРОВАННОЙ СТЕНКИ БАЛКИ ПРИ ЛОКАЛЬНОМ НАГРУЖЕНИИ}

Приведены результаты численного исследования методом конечных элементов (МКЭ) напряженного состояния гофрированной стенки балки при действии локальной нагрузки в её площади. Установлено, что величина локальных нормальных напряжений на уровне соединения стенки с поясом непосредственно зависит от толщины стенки, изгибной и продольной жесткости поясов и практически не зависит от высоты стенки. Разработана практическая методика определения величины локальных нормальных напряжений в стенке и ее предельного состояния.

Ключевые слова: гофрированная стенка, напряженно-деформированное состояние, условие прочности, локальное нагружение.

\section{УДК 624.014}

Семчук І.Ю., Нілова Т.О. Напружено-деформований стан гофрованої стінки балки при локальному навантаженні // Опір матеріалів і теорія споруд: наук.-тех. збірн. - К.: КНУБА, 2019. - Вип. 102.- С. 53-61.

Наведені результати чисельного дослідження за методом скінченних елементів напруженого стану гофрованої стінки балки при дї локального навантажування в ї̈ площині. Розроблена практична методика визначення величини локальних нормальних напружень в стінці і ї̈ граничного стану.

Табл. 2. Іл. 5. Бібліогр. 10 назв.

UDC 624.014

Semchuk I.Y. , Nilova T.O. Stress-strain state of beam corrugated web under patch loading // Strength of Materials and Theory of Structures: Scientific-and-technical collected articles - Kyiv: KNUBA, 2019. - Issue 102. - P. 53-61.

The results of a numerical study by the finite element method of the stressed state of a corrugated beam wall under the action of a local load in its plane are presented. A practical method was developed for determining the magnitude of local normal stresses in a wall and its limiting state. Tabl. 2. Fig. 5. Ref. 10.

УДК 624.014

Семчук И.Ю., Нилова Т.А. Напряженно-деформированное состояние гофрированной стенки балки при локальном нагружении // Сопротивление материалов и теория сооружений: науч.-тех. сборн. - К.: КНУСА, 2019. - Вып. 102. - С. 53-61.

Приведены результаты численного исследования методом конечных элементов напряженного состояния гофрированной стенки балки при действии локальной нагрузки в ее плоскости. Разработана практическая методика определения величины локальных нормальных напряжений в стенке и ее предельного состояния.

Табл. 2. Ил. 5. Библиогр. 10 назв.

Автор (вчена ступень, вчене звання, посада): магістр Семчук Ігор Юрійович. Адреса робоча: 03680 Україна, м. Київ, Повітрофлотський проспект 31, Київський національний університет будівниџтва і архітектури, кафедра металевих і дерев'яних конструкиій, Семчуку Ігору Юрійовичу.

Робочий тел.: +38(044) 248-31-17;

Мобільний тел.: +38(096) 201-57-68.

E-mail: semchuk7@ukr.net

Автор (вчена ступень, вчене звання, посада):кандидат технічних наук, доцент кафедри металевих і дерев'яних конструкцій КНУБА Нілова Тетяна Олексї̈вна. ORCID: 0000-0001-9282-8136

Адреса робоча: 03680 Україна, м. Київ, Повітрофлотський проспект 31, Київський національний університет будівництва і архітектури, кафедра металевих і дерев'яних конструкиій, Ніловій Тетяні Олексї̈вні.

Адреса домашня: 03087, Україна, Украӥна, м. Київ , вул. Ереванська б.8-а, кв.54.

Робочий тел.: +38(044) 248-31-17;

Мобільний тел.: +38(068) 128-30-62.

E-mail: tatic70@gmail.com 